\title{
Dictynna
}

Dictynna

Revue de poétique latine

$7 \mid 2010$

Varia

\section{Reflections: Two Letters, and two poets}

\section{Benjamin Acosta-Hughes}

\section{(2) OpenEdition}

\section{Journals}

Electronic version

URL: http://journals.openedition.org/dictynna/178

DOI: 10.4000/dictynna.178

ISSN: $1765-3142$

Electronic reference

Benjamin Acosta-Hughes, "Reflections: Two Letters, and two poets », Dictynna [Online], 7| 2010,

Online since 25 November 2010, connection on 10 September 2020. URL : http://

journals.openedition.org/dictynna/178; DOI : https://doi.org/10.4000/dictynna.178

\section{(@) $\odot \Theta \Theta$}

Les contenus des la revue Dictynna sont mis à disposition selon les termes de la Licence Creative Commons Attribution - Pas d'Utilisation Commerciale - Pas de Modification 4.0 International. 


\title{
Reflections: Two Letters, and two poets
}

\author{
Benjamin Acosta-Hughes \\ The Ohio State University \\ Università di Roma Tre (associato) \\ acosta-hughes.1@osu.edu
}

For J.D. Reed sodalis

\section{Introductory Note}

My work over the past several years has been largely concerned with Hellenistic poetry's reception of Sappho, and with the Roman response to that reception. In both Arion's Lyre: Archaic Lyric into Hellenistic Poetry (Princeton 2010) and Callimachus in Context: From Plato to Ovid (coauthored with Susan Stephens, Cambridge 2011 forthcoming) I have dealt extensively with the evolution of Sappho's poetry from song into text for a later audience, and with Sappho as a poetic model, and further with Callimachean Sappho as a model for Catullus. The paper that follows is something of a parergon of this work, and takes many of the ideas laid out in those studies as pre-assumptions. ${ }^{1}$ For a variety of reasons it never quite "fit" within the context of either of the above-mentioned works. I am grateful to J. Fabre-Serris for suggesting a home for it here.

The topic of the pages that follow here, the rapport of the two epistolary poems of Catullus (carmina 50 and 65) to the rendition of earlier poets that follow them (carmina 51 and 66) is not a new one: the reading

1 - See esp. Acosta-Hughes 2010: 62-82; Acosta-Hughes and Stephens 2011 (forthcoming) ch. 4.3 .

Dictynna $-\mathrm{n}^{\circ} 7-2010$ 
these pages offer, one that considers both pairs through the prism, as it were, of a Callimachean epigram (34 G.-P. = 2 Pf.) is, to the best of my knowledge, one that has not hitherto been explored.

Catullus has something of a parallel rapport with Sappho and Callimachus; he renders a poem of each Greek poet into Latin, in each case an adaptation to his own artistry and circumstances. Each poet he evokes, remarkably, by name (Catullus rarely so evokes earlier poets). ${ }^{2}$ The opening poem of his polymetrics, Callimachean in theme and imagery, is in a meter, the phalacean hendecasyllable, that is a primary one of the fifth book of Sappho. This parallel rapport is remarkable, and becomes the more so with closer consideration.

\section{I}

That c 50 is meant to "accompany" Catullus' adaptation of Sappho's

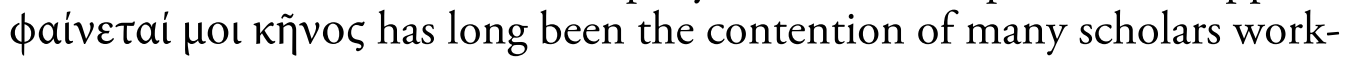
ing with this poem. Recently D. Wray has made a cogent case for the close association, highlighting the verbal and thematic links that bind the two poems. ${ }^{3}$ The parallel situation of Catullus 65 and 66, again a poem that adopts an "epistolary" form to introduce the accompanying translation (here of Callimachus' Lock of Berenice), encourages comparison of the two pairs. ${ }^{4} \mathrm{C} 65$, the poem that presents the Callimachus translation, is itself imbued with echoes of Sappho. I would contend that c 50, which has the same role in presenting the Sappho translation as 65 does in presenting the Callimachus one, is in turn imbued with subtle echoes of Callimachus. Each pairing in turn pairs Catullus' two models.

Hesterno, Licini, die otiosi multum lusimus in meis tabellis, ut convenerat esse delicatos: scribens versiculos uterque nostrum ludebat numero modo hoc modo illoc, reddens mutua per iocum atque vinum. atque illinc abii tuo lepore incensus, Licini, facetiisque, ut nec me miserum cibus iuvaret nec somnus tegeret quiete ocellos, sed toto indomitus furore lecto versarer, cupiens videre lucem, ut tecum loquerer simulque ut essem. at defessa labore membra postquam

2 - Another exception is Simonides (c.38.8).

3 - Wray 2001:95-100; see further Manwell 2007: 123-24 on Wray.

4 - On the "epistolary" characteristiccs of poem 50 see Syndikus 2001: 1. 250. 
semimortua lectulo iacebant, hoc, iucunde, tibi poema feci, ex quo perspiceres meum dolorem. 5

Yesterday, Licinius, at leisure we played a lot in my writing tablets, as we had agreed to be cute; each of us writing little verses played now with this meter now with that one, giving mutual pleasure with laughter and wine. From there I went away, on fire from your charm, Licinius, and your wit, so that neither was food any help to sorry me, nor did sleep touch my eyes with rest, but overcome with passion I kept tossing about all over the couch, wanting to see the light, that I might speak with you and be together with you. But after my limbs, half-dead with fatigue, lay exhausted on my little bed, I made this poem for you, from which you might appreciate my suffering. Now beware that you not sniff at my entreaties, or spite them, my love, for fear Nemesis demand payment from you. She's a powerful goddess - take care not to offend her.

Sappho fr. 31 is a self-description of the poet's own pathological reactions. ${ }^{6}$ Catullus effectively renders it twice (this dual rendition is itself a Hellenistic convention in the reception of this poem), ${ }^{7}$ with poem 50 the pathological reality of which c 51 is the artistic expression (the Roman reader would of course identify c 51 as a translation, though adapted). We can carry this one step further to note that c 50 portrays the external pathology (lack of appetite, sleep, impassioned state -line 8 incensus) ${ }^{8}$ of which 51 portrays the physical symptoms (speechlessness, sight darkened, etc.). ${ }^{9}$ This rapport of the two poems is heightened, as Wray observes, ${ }^{10}$ by the recall of 50.1 otiosi in 51.13-15: otium...otio... otium, and 50.9 miserum in 51.5 misero; the sleepless nocturnal experience of the speaker of 50 is juxtaposed by the fainting of 51.11-12: gemina teguntur|lumina nocte (whereas Sappho's seeming-death is transferred to 50.14-15: membra... (semimortua). Poem 50 is further, as Syndikus and others have observed, replete with Catullan erotic vocabulary: lepore (line 7), incensus (line 5), ocellos (line 10), iucunde (line 15), ocelle (line 19), as well as erotic double-entendre (line 5 ludebat, line 6 reddens mutua, line 13 simulque ut essem). One might go so far as to call poem 50 the homerotic version of the heteroerotic poem 51 (itself, we remember, originally

5 - Text of Catullus throughout is the 1958 OCT edited by R.A.B. Mynors.

6 - See most recently Ferrari 2007: 157-67.

7 - Both Theocritus (in Idyll 2) and Apollonius (in Argonautica 3) twice recreate Sappho fr. 31, see further Acosta-Hughes 2010 pp. 17-29 and 49-57.

8 - See also Batstone 2007: 243-45, who raises the pertinent question to what extent poem 50 has a progrmmatic function for the poem that follows it, a question also pertinent to the relationship between poems 65 and 66 .

9 - On the features of erotike nosos in this poem see Syndikus 2001: 253.

10 - Wray 2001: 95-98. 
a homoerotic poem), with the added feature that both are, though differently, poems of separation from the beloved.

The Callimachean resonances in c 50 come from a couple of texts; a comparative reading suggests not so much one intertext as a larger model in poetic voice. Callimachus Ep. 2 (GP 34) is a poem much studied from a variety of critical perspectives, and one that has some very intriguing parallel moments with c 50 .

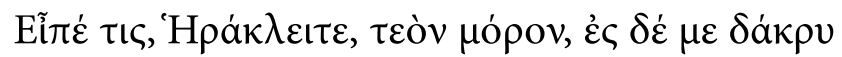

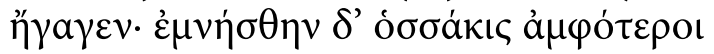

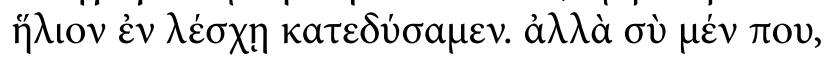

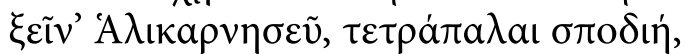

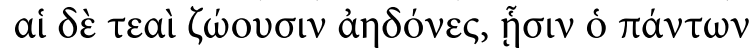

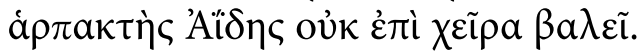

Someone told me, Heraclitus, of your death, and for me this brought forth a tear; for I remembered how often we both set the sun to sleep with our conversation. But you somewhere, I guess, Halicarnassian friend, are long dust. But your nightingales live on; on these Hades, that steals all away, will not set his hand.

In his posthumously published study of this poem, the late G. Walsh acutely articulated its very "modern" delineation of thought processes; a conventional epigram type (the epitaph) becomes rather only the template for construction of an interior conversation. ${ }^{11}$ The poet thinks of his friend, the pleasure of the time they shared, the absence of that association, and the friend's memory preserved through his poetry. The framing of the memory is homosocial rather than symposiastic, the memory of the distant association, ${ }^{12}$ while not tempered with the explicit erotic connotation of the Catullus poem, can nonetheless be read as one of pleasure and longing. The overall movement of the poem can be phrased as apostrophe, ${ }^{13}$ memory of time spent together, separation, poetry, final reference to destructive deity. ${ }^{14}$ And this is also one way of phrasing Catullus' poem to is friend Licinius Calvus.

11 - Walsh 1991.

12 - In the Callimachus epigram the association is one both temporally and spatially distant; Catullus presents the reverse, the friend is both close to the poet's recall in time (hesterno die) and space (atque illinc abii...ut tecum loquerer simulque ut essem).

13 - Walsh 1991: 1-3 well observes the enigma of the addressee in Callimachus' epigram; Heraclitus is present neither in death nor life, but remembered, although in a fractured way. Similarly might we ask of Catullus' addresee, Licinius Calvus, exactly how he is meant to be understood in relation to the poem - or is his memory only the fiction for the poem's creation?

14 - In a celebrated association of Nemesis, poet, and endearment, Callimachus ep. 21 Pf.

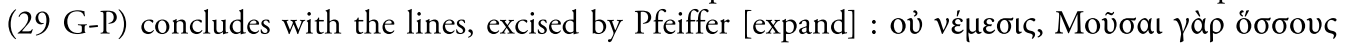

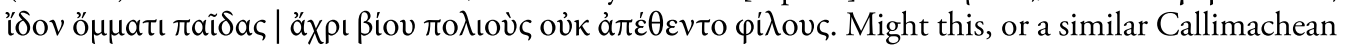
image, be what Catullus is varying here? 
Callimachus prefigures the Roman poets in his portrayal of the physicality of poetic composition, poetry as labor, though with a jocular touch,

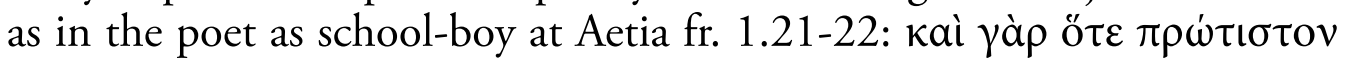

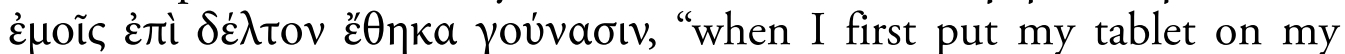
knees), 15 or Aratus' fine verses proof of his poetic sleeplessness at Ep. 56

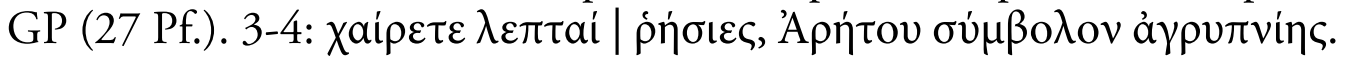
The references to writing, and also to reading, in his poetry lay the groundwork for what will evolve as the idea of poet qua métier among his Roman successors.

The last vivid image of the epigram, all-consuming Hades, does not appear recalled in Catullus' poem - but may be imitated at c.3,13-14: malae tenebrae | Orci, quae omnia bella devoratis, a differently figured personification of death (and an evocation of death that is also, here through enjambment, metrically remarkable). That one element of an intertext may occur elsewhere than in its more prominent imitation in a later poem is a prominent conclusion of J. Will's brilliant 1998 study; ${ }^{16}$ the suggestion here would then be that it might occur elsewhere in the same collection of short poems. I would argue that this indeed the case;

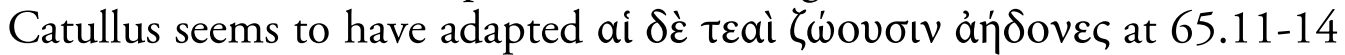
where he juxtaposes his eternal song of his brother with the conventional epic grieving nightingale, and it is to this poem that I now turn.

\section{II}

at certe semper amabo,

semper maesta tua carmina morte canam,

qualia sub densis ramorum concinit umbris

Daulias, absumpti fata gemens Ityli.

but surely I will ever love you, and will sing of your wretched death in my poetry, just as below the branches' heavy shades the Daulian nightingale sings, lamenting the death of perished Itylus.

Recalling here that 1. Catullus' brother dies far from him in the Troad and 2. that his grief for this death serves as the [aition] for sending his rendition of Callimachus, the echo seems all the more likely.

Poem 65 closes with an image that has affiliations to both Sappho and Callimachus:

ne tua dicta vagis nequiquam credita ventis,

effluxisse meo forte putes animo,

ut missum sponsi furtivo munere malum

15 - On this image see Acosta-Hughes and Stephens 2002: 243-4.

16 - Wills 1998: 288, 296. 
procurrit casto virginis e gremio,

quod miserae oblitae molli sub veste locatum,

dum adventu matris prosilit, excutitur,

atque illud prono praeceps agitur decursu,

huic manat tristi conscius ore rubor.

lest you believe your words, entrusted to wandering winds, to have flown by chance from my heart, as an apple, sent as a secret gift from her betroathed, an apple that the poor girl, forgetful, placed under her dress, suddenly, at her mother's advance, jumps forth from her lap, and as it rolls forth in its prone course before her, a guilty blush spreads over her sorrowful face.

Immediately juxtaposed to the expressa carmina Battiadae, the poems rendered of the Battiad, is an image long recognized as deriving in all likelihood in part from Callimachus, specifically from the apple Acontius gives Cydippe that betrays her into declaring her oath of marriage. ${ }^{17}$ The lines obliquely recall at the same time the imagery of a fragment from one of Sappho's wedding-poems (fr. 105a V.): ${ }^{18}$

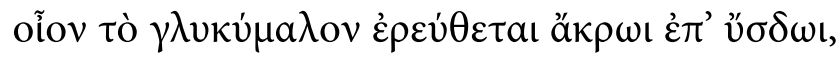

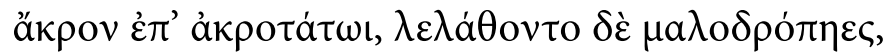

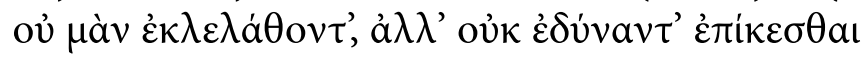

as the sweet apple reddens upon the highest branch, at the very highest point, the apple-pickers left it, not that they forgot it, but they were unable to reach it.

Of interest here is the nexus of apple, blush, forgetfullness and wedding poetry (epithalamia are usually in hexameters). The possible filiation to Sappho comes the more into focus when we consider the amount of recall of Sappho's poetry in the Acontius and Cydippe episode itself, not only in Callimachus' narrative of the erotike nosos, ${ }^{19}$ but particularly the initial description of Cydippe herself (fr. 67.11-14 Pf.):

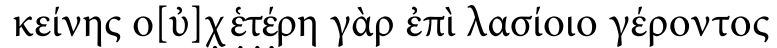

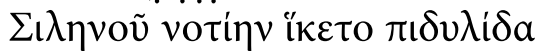

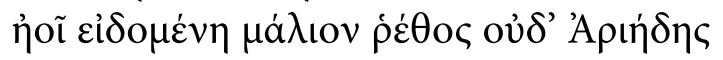

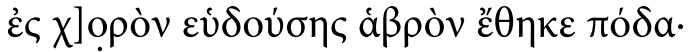

17 - See most recently Hunter 1993.

18 - The question of whether Sappho's epithalamia constituted a separate book of her poetry in the Alexandrian edition of her verse is a complex one. See Acosta-Hughes 2010: 99-103: Yatromanolakis 1999.

19 - Acosta-Hughes 2010: 81-82. 
Than her no other came to the wet little spring of the hairy old man with a face more like the dawn, nor set soft foot in the chorus of sleeping Ariadne.

Redolent of Sappho here is the term rhethos, the comparison with a celestial feature, and the "soft foot" (habron poda). Cydippe is portrayed in this Delian context as one of a chorus of young girls who have come to take part in the ritual festivities, and it is in this context that Acontius first sees Cydippe. The evocation of Sappho's poetry in Callim. fr. 75 is preceded by a similar evocation in fr. 67 - and indeed, there are few other poets (possibly Pindar, possibly Alcman) to whom Callimachus would have turned in his portrayal of Cydippe as one of a chorus of young girls.

With this image of the rolling apple lost to a young girl Cat. 65 "transitions" to a poem whose central image is a lost lock of hair dedicated as a votive offering for a husband's safe return from a foreign war (the Third Syrian War). Here the dedication is made after the young woman's wedding-night (Cat. 66.13-15: dulcis nocturnae portans vestigia rixae, | quem de virgineis gesserat exuuiis, though the lock refers back to the period (here and in the Callimachus version) where Berenice was an unwed girl (lines 25-28). The journey of a lost munus of 65.19 then finds a reflection in the novo munere of 66.38 and in the munera of 66.82 .

\section{Conclusion}

Paired poems are a feature of Catullus' oeuvre, whether in the polymetrics (e.g. carmina 2 and 3; 5 and 7), or even, among the longer poems, 61 and 62, both epithalamia with marked allusions to Sappho. The quatrain formed by 50, 51 and 65, 66 suggests something compositionally more complex, paired poems that reflect another pair, pairings in which Catullus paired poetic models, Sappho and Callimachus, play a distinct compositional roles. Each pair comments on Catullus' rapport with both earlier artists, and, most importantly, the implication of Sappho in Callimachus. 


\section{References Cited}

Acosta-Hughes, B. 2010. Arion's Lyre. Archaic Lyric into Hellenistic Poetry. Princeton.

Acosta-Hughes, B. and S. Stephens. 2002. "Rereading Callimachus' Aitia Fr. 1." CP 97: 238-55.

Batstone, W. 2007. "Catullus and the Programmatic Poem: The Origins, Scope, and Utility of a Concept." In Skinner 2007: 235-53.

Ferrari, 2007. Una mitra per Kleis: Saffo e il suo pubblico. Pisa.

Hunter, R. 1993. "Callimachean Echoes in Catullus 65." ZPE 96: 179-82.

Manwell, E. 2007. "Gender and Masculinity." In Skinner 2007: 111-28.

Skinner, M. B., ed. 2007. A Companion to Catullus. Oxford.

Syndikus, H. P. $2001^{2}$. Catull. Eine Interpretation. 3 vols. Darmstadt: Wissenschaftliche Buchgesellschaft.

Van Sickle, J. 1968. "About Form and Feeling in Catullus 65". TAPA 99: 487508.

Walsh, G. B. 1990. "Surprised by Self: Audible Thought in Hellenistic Poetry." CP 85: 1-21.

Wills, J. 1998. "Divided Allusion: Virgil and the Coma Berenices" Harvard Studies in Classical Philology 98:277-305.

Wray, D. 2001. Catullus and the Poetics of Roman Manhood. Cambridge.

Yatromanolakis, D. 1999. “Alexandrian Sappho Revisited.” HSCP 99: 179-95. 